\title{
RELIGIÃO E NEGACIONISMO NO CENÁRIO DA PANDEMIA DA COVID-19
}

\author{
Religion and negacionism the Covid-19 pandemic scenario
}

\author{
Maximiliano Martin Vicente ${ }^{1}$ \\ Bruna de Mello Franco ${ }^{2}$
}

\begin{abstract}
RESUMO
$\mathrm{O}$ artigo tem por finalidade analisar como a mídia contribui para gerar impactos para o ambiente político e de saúde pública na medida em que se torna transmissora de conteúdos e produtora de sentidos. O objeto de análise se trata de um pronunciamento em vídeo realizado pelo Pastor Silas Malafaia, líder da igreja Assembleia de Deus Vitória em Cristo, intitulado: "O ódio a Bolsonaro e às religiões em tempo de pandemia". Para responder ao objetivo estabelecido o artigo se divide em três partes. Na primeira se trata da religião midiatizada e tem como base autores como Martino, Martin-Barbero, Peña-Alfaro, Gouvêa Neto, entre outros. Num segundo momento se aborda a questão da pandemia, privilegiando o antagonismo protagonizado pelas argumentações entre os isolacionistas (partidários da adoção de medidas restritivas) e os negacionistas (defensores da abertura e do relaxamento do isolacionismo). Os autores que se utilizam são Caponi, Berardi Andreen, Gottschall e Santos. No terceiro subitem, usando como referência a Análise do Conteúdo de Laurence Bardin (2006) e levando em consideração os itens anteriores, se discute o vídeo selecionado. Para isso se criaram três categorias de análise para identificar os posicionamentos de Silas Malafaia. Finalmente, nas considerações finais, se apresentam os resultados obtidos.
\end{abstract}

Palavras-chave: Religião. Negacionismo. Pandemia. Silas Malafaia.

\begin{abstract}
The article aims to analyze how the media contributes to generate impacts on the political and public health environment to the extent that it becomes a transmitter of content and producer of meanings. The object of analysis is a video statement made by the minister Silas Malafaia, leader of the church Assembleia de Deus Vitória em Cristo (Victory in Christ Assembly of God), entitled: "The hatred of Bolsonaro and religions in a time of pandemic. To answer the established objective, the article is divided into three parts. The first part deals with religion in the media and is based on authors such as Martino, Martin-Barbero, Peña-Alfaro, and Gouvêa
\end{abstract}

\footnotetext{
${ }^{1}$ Graduação em História pela Universidade do Sagrado Coração (1982), mestrado em História pela Universidade Estadual Paulista Júlio de Mesquita Filho (1987) e doutorado em História Social pela Universidade de São Paulo (1996). Livre-docente em História do Brasil em 2008. Atualmente é professor da Universidade Estadual Paulista Júlio de Mesquita Filho, UNESP, no campus de Bauru. Tem experiência no ensino nos cursos de Comunicação Social, na área de História do Brasil e Realidade Socioeconômica e Política Brasileira Contemporânea. Atua no programa de Pós-Graduação em Comunicação Midiática da UNESP onde orienta pesquisas na área de processos Midiáticos e Práticas Socioculturais e leciona a disciplina Comunicação e História na Nova Ordem Internacional. Desenvolve pesquisas relacionadas a comunicação alternativa e contra hegemônica.

${ }^{2}$ Graduada em Publicidade e Propaganda pela Universidade do Sagrado Coração - USC (Bauru - SP. Atualmente é bolsista como Facilitadora de cursos na Universidade Virtual do Estado de São Paulo (UNIVESP) e é pesquisadora desenvolvendo o projeto de mestrado sobre comunicação, religião e política no Programa de PósGraduação em Comunicação (PPGCom) na Faculdade de Arquitetura, Artes, Comunicação e Design (FAAC) UNESP, Campus de Bauru. É participante do Grupo de Pesquisa Mídia e Sociedade e tem interesse nos estudos da Comunicação na era Digital; Comunicação, cultura e sociedade; Processos midiáticos; Práticas Socioculturais. REVISTA RELEGENS THRÉSKEIA - 2021 - UFPR
} 
Neto, among others. In a second moment, the issue of the pandemic is approached, focusing on the antagonism between the isolationists (supporters of the adoption of restrictive measures) and the deniers (advocates of openness and relaxation of isolation). The authors used are Caponi, Berardi Andreen, Gottschall and Santos. In the third sub-item, using Laurence Bardin's (2006) Content Analysis as a reference and taking into account the previous items, the selected video is discussed. To this end, three categories of analysis were created to identify Silas Malafaia's positions. Finally, in the final considerations, the results obtained are presented.

Keywords: Religion. Negationism. Pandemic. Silas Malafaia.

\section{Introdução}

Nas últimas décadas a comunicação teve seus processos reconfigurados de maneira constante à medida que as mudanças dessas dinâmicas de troca de informações também reestruturam comportamentos sociais, culturais e econômicos. Para Castells (2013) as redes possuem capacidade de inserir, além de novos agentes, novos conteúdos no processo de sistematização da sociedade já alertando para a relativa autonomia que se tem nesse meio que o autor chama de centros do poder.

O presente artigo tem por finalidade analisar como a mídia, dentro de um cenário em que pronunciamentos religiosos são potencializados pelos diferentes meios de comunicação, especificamente as redes sociais digitais, contribui para gerar impactos relevantes para o ambiente político e de saúde pública na medida em que não é apenas uma mera transmissora de conteúdo, mas também produtora de sentidos. O objeto de análise se trata de um pronunciamento em vídeo realizado pelo pastor Silas Malafaia, líder da igreja Assembleia de Deus Vitória em Cristo.

$\mathrm{O}$ vídeo intitulado "O ódio a Bolsonaro e às religiões em tempo de pandemia" foi veiculado por meio do canal oficial do líder no Youtube, uma de suas várias redes sociais que acumulam milhares de seguidores. O material tem 9 minutos e 41 segundos de duração e conta apenas o pastor como participante, sendo que este se encontra sentado em uma mesa de escritório falando diretamente com a câmera, sem qualquer trilha sonora ou elemento adicional. Foi postado em 27 de agosto de 2020 e até a data da elaboração desse artigo contava com 117.110 mil visualizações, cerca de 20 mil likes e 697 deslikes.

Para responder ao objetivo estabelecido o artigo se divide em três partes. Na primeira se trata da religião midiatizada. A pretensão desse primeiro item, tendo como base metodológica a exploração teórica bibliográfica, é auxiliar na compreensão da dinâmica que a 
religião adquire em tempos em que a midiatização se torna cada vez mais atuante e decisiva na formação de versões e intepretações das questões sociais.

Num segundo momento se privilegia a questão da pandemia, pano de fundo da finalidade do vídeo selecionado para análise. Nesse segundo inciso se mostram as repercussões, abordagens e debates suscitados pelo Covid-19, privilegiando o antagonismo protagonizado pelas argumentações entre os isolacionistas (partidários da adoção de medias restritivas) e os negacionistas (defensores da abertura e do relaxamento do isolacionismo).

Tratando-se de uma pesquisa qualitativa com caráter exploratório, na terceira parte, levando em consideração os itens anteriores, tem-se como referência a Análise de Conteúdo de Laurence Bardin (2016) para discutir o vídeo selecionado no intuito de identificar os recursos utilizados por Silas Malafaia ao defender seus pontos de vista claramente negacionistas e de defesa ao atual presidente Jair Bolsonaro. Para isso se criaram categorias de análise para identificar os posicionamentos de Silas Malafaia.

Finalmente se tecem algumas conclusões destinadas a identificar formas de influência do posicionamento religioso no processo de formação da opinião pública.

\section{Mídias e religião no contexto atual}

Quando se fala em mídia comumente liga-se o termo aos meios e veículos de comunicação que realizam os processos de transmissão de informações, sejam as mais tradicionais como também as digitais que ganharam espaço dominante na sociedade nas últimas décadas. Cunha (2016) destaca que as normas sociais, bem como as relações e organização do corpo social, são regidas pelas referências do que a autora denomina como cultura midiática, tendo como base seus princípios mais primordiais tais como a lógica atemporal, conectividade e não-linearidade.

Martino (2012) define esse contexto como produto dessas mediações e entende que o processo de midiatização pode ser compreendido como resultado das transformações da contemporaneidade ao considerar o avanço dos meios eletrônicos e digitais que fazem parte do escopo da comunicação, tornando as mídias não apenas como transmissoras de informações e mensagens, mas também como agentes produtoras de sentido dentro da sociedade.

Assim, é viável a compreensão do papel da mídia e seus processos enquanto parte das referências das práticas sociais e no que se refere à formação de opinião pública, uma vez que pensar a utilização dos recursos tecnológicos como neutros seria ignorar sua função interativa nas construções intelectuais dos indivíduos. Para Martín-Barbero (2006) as tecnologias, 
enquanto mediadoras de informação, podem configurar conjuntos sólidos e interativos relacionados até mesmo à interesses econômicos e políticos atuando por meio das mediações sociais e embates simbólicos, sendo que justamente por esses aspectos acabam por constituírem novas formas de concepção de opinião pública. A questão da religião não foge a essa conceituação do papel das mídias.

Segundo Martino (2012, p. 222), “a midiatização vem se afirmando como uma característica preponderante de várias igrejas e grupos religiosos, alterando práticas religiosas que são reconfiguradas e repensadas no contexto de uma sociedade igualmente midiatizada". O autor apresenta a ideia de que a midiatização no contexto religioso trouxe mudanças não só para as práticas do âmbito religioso, como também inseriu novas dinâmicas internas na esfera da comunicação. Para ele "a midiatização da religião não acontece dissociada do universo simbólico das mediações do receptor, que chega à experiência religiosa midiatizada provido de um repertório de símbolos, práticas e expectativas de mediação em relação ao religioso" (MARTINO, 2012, p. 231).

Bratosin (2017) enfatiza que a relevância da midiatização da religião se encontra nas diferentes formas de se apresentar o religioso, além de promover alterações na transmissão das informações religiosas, ou seja, uma mudança de conteúdo e prática em si. Nodari e Krindges (2014) apresentam a ideia de que dentro desse universo de mudanças nos processos de comunicação também acontecem alterações no campo religioso, pois se há alguns anos as Igrejas utilizavam os meios de comunicação como forma de evangelizar, na atualidade possuem canais de mídia exclusivos e próprios, além de terem aumento da visibilidade ao exibirem suas programações em horários nobres.

Martino (2012) complementa dizendo que a midiatização da religião não se altera apenas em suas práticas, mas também apresenta uma remodelagem vasta nas significações do "religioso", "sagrado" e até mesmo da experiência religiosa dentro de uma sociedade midiatizada, sendo que na época em que as mídias se convergem, além de emitirem conteúdo, elas também “[...] promovem encontros, debates, geram informação e divulgam eventos [...]" (CUNHA, 2016, p. 14). A socialização ampliada que se torna possível pelas mídias digitais é facilitadora de intercâmbios entre grupos internos e externos às igrejas - uma nova forma de evangelização. Martino ainda destaca que a visibilidade das igrejas adquiridas por meio do uso das mídias faz com que o número de fiéis aumente e consequentemente se estende a força política da instituição, dando-lhe um caráter mais legítimo enquanto "instância representativa dos princípios de um contingente de pessoas”. (MARTINO 2012, p. 233). 
Sem ignorar a presença católica no espaço midiático, como padres que trazem celebrações e shows musicais nos veículos de comunicação, há de se enfatizar a questão da visibilidade das instituições evangélicas. Martino (2012) constata que as igrejas do país que mais demonstram crescimento significativo nos últimos anos são justamente aquelas que obtiveram maior êxito no que se refere ao diálogo com os meios de comunicação, como exemplos a Igreja Renascer em Cristo, Igreja da Graça, Igreja Mundial do Poder de Deus, Igreja Universal do Reino de Deus, entre outras. Nodari e Krindges (2014) mencionam a relação entre sistema midiático e mercado que inevitavelmente abarcam o campo da religião, uma vez que as pessoas são disputadas a vivenciar a fé por meio do virtual, salientando que mesmo que os ambientes das redes virtuais de relacionamento passem por mudanças repentinas, essas colaboram para o surgimento de novas comunidades de pertencimento.

Cunha (2016) lembra que a década de 90 foi marcada pelo início da consolidação dos chamados impérios de mídia das Igrejas no Brasil, tendo como uma das principais a Igreja Universal do Reino de Deus, uma vez que os dirigentes da instituição fazem parte das 11 famílias que são donas da mídia do país, sendo que o conteúdo transmitido por seus veículos são diversificados e abrangem o não religioso também. A emissora se estabelece na segunda colocação dos canais televisivos com maior audiência no Brasil com a Rede Record. "Seguemse à IURD a Igreja Internacional da Graça de Deus, a Igreja Renascer em Cristo e a Igreja Católica Romana." (CUNHA, 2016, p. 6).

Lembrando que esses canais se estendem para além da mídia tradicional. As mídias digitais são vias cada vez mais exploradas dentro do cenário evangélico, tendo as redes sociais como forma de se aproximar dos fiéis. Os líderes religiosos das igrejas citadas no parágrafo anterior tais como Silas Malafaia, R.R Soares e Edir Macedo possuem contas oficiais em redes sociais digitais como Youtube, Instagram, Twitter e Facebook, onde postam mensagens por meio de vídeos, textos e transmissões ao vivo com conteúdo religioso e até mesmo assuntos que são populares do momento, principalmente se envolverem questões políticas, sociais e culturais que possam interferir em valores morais, princípios e concepções da doutrina cristã.

Gouvêa Neto (2017) identifica que os evangélicos, ao transformarem a sua mensagem com o amparo dos meios de comunicação, acabam por instaurar um novo padrão de vida e alteram a percepção do fiel sobre ele e seu grupo surgindo uma espécie de nova identidade evangélica. "A dimensão da participação e da transformação dos receptores em emissores, por meio de processos de interação possibilitados pelas novas mídias, especialmente, pela internet, mudou radicalmente o quadro da relação igrejas-mídias" (CUNHA, 2014, p. 288). 
A população evangélica foi a que mais obteve crescimento no Brasil entre 1980 e 2000 "saltando de 15,6\% da população em 2000 para 22,2\% da população em 2010, o que representa em números absolutos um aumento de 20,1 milhões de adeptos" (GOUVÊA NETO, 2017, p. 323). Uma pesquisa realizada pelo Datafolha e publicada em janeiro de 2020, apontou que 50\% da população é católica e $31 \%$ da população é evangélica, constatando ainda que os evangélicos podem superar os católicos em números em pouco mais de uma década (G1, 2021). Com o aumento da presença do público nas redes, com ênfase nos grupos pentecostais e neopentecostais, houve uma reconfiguração no cenário em que a religião agora também se contextualiza no espaço midiático. Ocupando mais lugares na sociedade, entende-se que suas vozes também ecoam em maiores proporções e intensidade colaborando para a construção de identidades e opinião pública, sendo que para entender como ocorre esse processo faz-se necessário compreender os tipos de apelos que são utilizados nessas narrativas.

Peña-Alfaro (2005) tem o discurso religioso como mediador de práticas sociais, uma vez que se trata de um recurso que prega e divulga todo um sistema que agrega crenças, questões de valores morais, éticos e de espiritualidade, tais como "[...] visões de mundo e do homem, que são transmitidos, validados e legitimados através de práticas sociais no interior de uma instituição definida como religiosa pelos membros participantes ou por outros fora dela, nos quais busca adesão". (PEÑA-ALFARO, 2005, p. 56). Considerando essa circunstância em que a mensagem religiosa serve como mediadora e pode validar comportamentos sociais, compreende-se a importância que Gouvêa Neto (2017) aponta ao dizer que quando os evangélicos fazem uso dos recursos midiáticos e do espaço político para reivindicar seus carecimentos religiosos eles reconhecem sua pujança e poder representativo.

Essa repercussão pode ser relacionada ao fortalecimento da chamada bancada evangélica no Congresso Nacional. Segundo a matéria publicada na Uol (2020) "Em 1994, eram 21 deputados federais evangélicos, hoje já são 105 deputados e 15 senadores, o que equivale a $20 \%$ do Congresso". Considerando essa aproximação significativa dos religiosos no campo da política é possível compreender a força que os membros das igrejas pentecostais e neopentecostais possuem para recorrerem às demandas que atendam às suas respectivas pautas e comunidade em geral, uma vez que aderem uma natureza conservadora aos debates e leis apresentadas nos últimos tempos. Silva (2017) aponta que alguns temas como a descriminalização do aborto, casamento civil para pessoas do mesmo sexo, eutanásia e outros assuntos que abrangem cânones, bem como valores morais das igrejas, tornam-se tabus nas discussões de política no país. O autor complementa dizendo que “[...] os parlamentares eleitos 
pela Igreja católica e Igrejas neopentecostais formam coalizões políticas para frear iniciativas que interfiram no status quo, notadamente na conservação dos valores morais" (SILVA, 2017, p. 249).

Essa busca pela preservação de valores e princípios de suas doutrinas pode se tornar algo que oferece riscos às comunidades minoritárias da sociedade, tendo em vista que a parcela religiosa e conservadora do legislativo tem como um de seus encargos barrar as tentativas de consolidação de seus direitos. Há também a possibilidade do aumento dos índices de intolerância provenientes dos grupos sociais que compõem a esfera religiosa evangélica e que compactuam com os discursos proferidos pelos membros das Igrejas presentes no campo político.

Gouvêa Neto (2017) destaca pontos sobre as consequências do discurso religioso dos líderes evangélicos evidenciando a heterogeneidade destes, bem como a variedade de práticas e condutas, segundo a qual "[...] a ideia de se defender os valores cristãos - morais e éticos são trazidos para a esfera pública através dos meios de comunicação e chegam a repercutir na política brasileira". (GOUVÊA NETO, 2017, p. 327). Nesse sentido se faz necessário entender a relevância da junção entre política e religião na esfera dos pronunciamentos, visto que inclui visualizar o campo dos apelos existentes dentro de ambas as esferas. Ao que leva até mesmo a análise sobre o ponto de vista linguístico, sendo que Peña-Alfaro (2005) ressalta que é possível classificar o discurso religioso enquanto prática social e discursiva que tem potencial de disseminar sistemas de crença, valores que envolvem moral, espiritualidade e ética, como "[...] visões de mundo e do homem, que são transmitidos, validados e legitimados através de práticas sociais no interior de uma instituição definida como religiosa pelos membros participantes ou por outros fora dela, nos quais busca adesão" (PEÑA-ALFARO, 2005, p. 56).

Considerando esses aspectos, os receptores obtém as mensagens como guia de comportamentos e régua moral, uma vez que muito além das representações na política, a representação do líder religioso à frente de uma igreja agrega à ele credibilidade, segurança e visibilidade, visto que além da responsabilidade a ele conferida por estar à frente de um público fiel, há o que Peña-Alfaro (2005) denomina como recurso de autoridade o qual ele identifica como a proferição de um discurso que é endossado pela autoridade divina de Deus, ou seja, fala-se sempre em nome de Deus. Logo, a força da palavra do líder também provém desse apelo e daí a potencialização para a capacidade do convencimento, sendo que "este talvez seja o elemento mais importante para dar ao discurso religioso a ênfase retórica da qual é investido 
para conseguir os efeitos e produção de sentido desejados pelos pregadores religiosos nas suas mensagens dirigidas ao público escolhido" (PEÑA-ALFARO, 2005, p. 57).

Quando se fala sobre esses outros atores é possível retomar o assunto aqui tratado, a influência da religião e seus líderes enquanto agentes formadores de opinião. Valla (2002) fala sobre a relação das Igrejas pentecostais e neopentecostais - tendo-as como mediadoras do diálogo com o público - com as questões de políticas públicas e saúde pública, visto que segundo o autor, existe uma proposição de que há uma aproximação muito significativa entre religião e saúde, considerando os discursos religiosos que possuem teores milagrosos e de proteção divina, sendo que o autor classifica esse fenômeno como uma "crise de compreensão" sobre os assuntos externos a fé.

\section{Religião e negacionismo no cenário da pandemia}

A pandemia ocasionada pelo Covid-19 afetou rapidamente a estrutura social, política, cultural e econômica na qual o mundo se assentava. A maneira de abordar e enfrentar os impactos dessa crise mundial variou de governo para governo, assim como gerou debates e controvérsias entre intelectuais em todo o mundo. Enquanto uns defendiam o isolamento como a melhor forma de evitar a propagação do vírus, outros estimulavam a manutenção das atividades presenciais minimizando as dimensões da pandemia ${ }^{3}$. Essas divergências se sustentaram com argumentos que merecem ser detalhados em função da repercussão e expectativas geradas na sociedade diante do pouco conhecimento do vírus que se tinha no final de 2019 e início de 2020. Na essência se criou um antagonismo em torno da seguinte questão: o isolamento e distanciamento social como forma de evitar a propagação do vírus (isolacionistas) x manutenção das atividades presenciais como imperativo econômico e social para minimizar os impactos da pandemia (negacionistas).

Berardi (2020), Caponi (2020) e Santos (2020) alinhados com o isolamento e o distanciamento social entenderam que a pandemia levantou uma questão relacionada ao modelo neoliberal no qual se prioriza o lucro privado sobre o interesse social. Como resultado dessa prioridade, se teriam destruído os sistemas de saúde pública, além da acentuação das desigualdades sociais e a redução das verbas para pesquisa. Como afirma Santos (2020, p. 24)

\footnotetext{
${ }^{3}$ No Brasil, membros do Governo Federal endossaram fortemente campanhas de tratamento precoce e teorias negacionistas a respeito do vírus, em especial o Presidente da República Jair Messias Bolsonaro. Em contraposição estavam alguns Governadores de Estado como João Dória (SP) e Flávio Dino (MA) defendendo as medidas de isolamento apresentadas pela OMS. Em abril de 2020 o STF decide que os Estados e municípios teriam autonomia para conduzir as medidas de saúde indo contra a MP do Governo Federal que visava centralizar essas ações na União.
} 
“[...] esta versão do capitalismo sujeitou todas as áreas sociais ao modelo de negócio do capital e devem ser geridas de modo a gerar o máximo lucro para os investidores. Este modelo põe de lado qualquer lógica de serviço público". Nesse sentido Caponi (2020, p. 11) reforça a visão de Santos quando afirma que,

[...] o que o coronavírus deixou em evidência é que a saúde, como a educação, não pode ser pensada em termos neoliberais de investimento e capital, que a saúde não é um bem de mercado que deve ser adquirido na medicina privada, deixando a saúde pública para aqueles que não podem pagar. A pandemia mostra que estamos todos expostos, pobres e ricos, velhos e jovens, aqueles que podem e aqueles que não podem pagar um plano de saúde.

Berardi (2020) estudando o sistema europeu de saúde afirma que “[...] o regime autoritário neoliberal cortou um quinto das unidades de terapia intensiva. Um terço dos clínicos gerais. As clínicas privadas investiram em terapias caras para os ricos, enquanto o empobrecido sistema público abandonou a produção de máscaras sanitárias”.

Em relação à economia os isolacionistas sustentam que a crise econômica não foi gerada pela pandemia, embora reconheçam que essa teria se acentuado no começo de 2020. Ela já vinha se desenhando nos anos anteriores afetando de maneira mais direta os menos favorecidos que dependiam das políticas públicas prejudicadas pelas carências econômicas sofridas pelos Estados (CARRANÇA, 2021). Entretanto, defendiam a ideia de que quanto mais radical fosse o isolamento antes se regressaria à normalidade, isso porque ao se diminuir as aglomerações e o contato entre as pessoas - forma mais conhecida naquele momento de transmissão do coronavírus - se reduziria a taxa de propagação e consequentemente aceleraria a recuperação econômica com a volta ao trabalho, tal como acontecia antes da pandemia.

Vale a pena lembrar que ainda no começo de 2020 testavam-se as vacinas contra o coronavírus, mas a eficácia destas ainda não era comprovada, além dos possíveis efeitos colaterais que essas poderiam ocasionar. Mesmo assim laboratórios e farmacêuticas começaram a desenvolver vacinas logo depois do surgimento dos primeiros casos ainda na China em 2019, de tal forma que no começo de 2020, apesar das dúvidas persistentes que se vislumbravam, os isolacionistas já consideravam a vacina como grande arma no combate ao coronavírus.

Ainda nesse momento inicial os dados publicados por diversos países e utilizados pelos isolacionistas comprovavam que aqueles que agiram prontamente para impedir e evitar as aglomerações de qualquer tipo, particularmente as reuniões em espaços de sociabilidade como festas, igrejas, restaurantes e shoppings, como sustenta Perini (2019), obtinham melhores resultados que aqueles que mantiveram suas atividades sem restrições. 
Por outro lado, os críticos do isolamento encontraram no negacionismo um basto arsenal para rebater os argumentos isolacionistas. Adotamos a perspectiva negacionista defendida por Penaforte (2021, p. 8) para quem "[...] o negacionismo pode ser definido como um fenômeno que busca rejeitar proposições empiricamente sustentadas e de consenso científico para criar uma falsa aparência de debate, uma vez que esse é inexistente". Assim, os negacionistas abrem espaço para produzir dissenso e sustentar convicções pessoais e ideológicas, livres de qualquer comprovação cientifica. Os negacionistas da pandemia

[...] passaram a desqualificar e agredir os cientistas e o discurso científico, sem necessariamente argumentar de fato sobre a dúvida gerada. Logo, apresentaram uma narrativa que se encaixava em valores compartilhados por determinados grupos, em sua maioria conservadores. Assim se tornaram comuns as narrativas que defendem a ideia de que os leitos de hospitais vazios, os laudos falsos e os caixões enterrados sem ninguém fariam parte de uma conspiração política para destruir governos de extrema-direita. (MOREL, 2021, p. 4).

Ainda segundo Morel (2021) o triunfo dessa visão se deve à determinados grupos de matriz conservadora como os neopentecostais, por exemplo, que reforçam valores criando identidades e fortalecendo as ideias contrárias às evidências cientificas. Identificavam os grupos inimigos - chineses, feministas, comunistas, gays, entre outros - como os defensores das ideias isolacionistas, portanto, careciam de credibilidade por representar segmentos específicos de determinados grupos e não de interesse geral.

Uma identidade alinhada ao pensamento liberal, como é o Instituo Mises ${ }^{4}$, produziu material abundante contra as medidas restritivas, material esse, como veremos a seguir, utilizado pelo presidente Jair Bolsonaro em seus ataques contra o isolacionismo. Andreen (2020) diz que as medidas adotadas pelos países partidários do isolamento conseguiram colapsar a atividade econômica do ocidente. Para ele pior do que a crise sanitária seria a crise econômica, pois

[...] populações inteiras foram submetidas a algo semelhante a uma ordem de prisão domiciliar, ficando confinadas em suas casas por semanas, se não meses. Como resultado, milhões tiveram suas vidas completamente alteradas. A maioria dos empresários e trabalhadores autônomos teve seus meios de subsistência comprometidos (ANDREEN, 2020, p. 1).

\footnotetext{
${ }^{4}$ De acordo com o site da organização “O Instituto Ludwig von Mises - Brasil (IMB) é uma associação voltada à produção e à disseminação de estudos econômicos e de ciências sociais que promovam os princípios de livre mercado e de uma sociedade livre". Acrescentando que defendem a ideia de sociedade livre respeitando à propriedade privada, à ordem natural dos mercados sem interferência dos governos.
} 
De maneira ainda mais explicita Gottschall (2020, p. 1) afirma que o isolamento implicava em "destruir empresas e empregos, obrigar todo mundo a ficar trancado em casa. Proibir as pessoas de se aproximarem nunca foi cura para vírus em nenhum lugar e em nenhum momento da história do mundo". De acordo com ele, para a grande maioria dos vírus nem todas as pessoas precisam ser infectadas para se tornarem imunes e nem todas precisam de uma vacina caso ela seja descoberta. Afirma que a imunidade é alcançada quando uma determinada porcentagem da pulação já contraiu alguma forma do vírus, com ou sem sintomas. E então o vírus efetivamente morre. Obviamente, para isso, as pessoas devem continuar com sua vida cotidiana como se nada de grave estivesse acontecendo.

Gottschall (2020) alerta para a hipocrisia do isolamento quando mostra que os países defensores das medidas restritivas “[...] quase proíbem de andar nas ruas, mas permitem que passageiros se aglomerem, encostando-se em ônibus superlotados, pois a frota é insuficiente para a demanda. Nesse caso, curiosamente, não há controle". O mesmo aconteceria com as máscaras. Para ele máscaras não protegem contra o vírus como a grande mídia apregoava, provocam o efeito contrário já que “[...] as máscaras prejudicariam a respiração, pois o ar expirado, rico em dióxido de carbono, é re-inalado, o que aumenta a acidificação do sangue e favorece o vírus".

No caso do Brasil ocorreu um debate logo que se detectaram os primeiros casos de contágio envolvendo isolacionistas e negacionistas: o tratamento precoce. Um dos negacionistas mais destacados na defesa do uso da hidroxicloroquina e a cloroquina ${ }^{5}$, como forma de combater o coronavírus, foi Hélio Beltrão, presidente do Instituto Mises Brasil. Beltrão também é herdeiro do Grupo Ultra, dono da Extra-farma, uma das maiores distribuidoras de remédios do país. Outro é Renato Spalicci, presidente da farmacêutica Apsen, que fabrica o Reuquinol, cuja caixa do medicamento Bolsonaro mostrou até aos líderes do G20. Os grupos empresariais envolvidos na defesa do tratamento precoce e a sua (in)eficácia foram tratados detalhadamente por Oliveira (2020), mas se mostram identificados com os defensores do negacionismo.

Embora não se tenha como comprovar, por enquanto, a relação entre as empresas farmacêuticas e o governo na defesa da hidroxicloroquina e a cloroquina, a NOTA

\footnotetext{
5“"Em março do ano passado, a OMS lançou uma série de pesquisas padronizadas sobre potenciais tratamentos para a doença. Entre os medicamentos analisados, estava justamente a hidroxicloroquina. Em julho, a organização suspendeu os estudos de forma definitiva, depois que os pesquisadores concluíram que a droga não reduziu a mortalidade de pacientes hospitalizados, mesmo com sinais de segurança associados ao uso do medicamento". (CCN, 2021).
} 
INFORMATIVA N 6/2020-DAF/SCTIE/MS de primeiro de abril de 2020, pelo Ministério da Saúde, sustentava que:

[...] o Ministério da Saúde do Brasil disponibilizará para uso, em casos confirmados e a critério médico, o medicamento cloroquina como terapia adjuvante no tratamento de formas graves, em pacientes hospitalizados, sem que outras medidas de suporte sejam preteridas em seu favor. A presente medida considera que não existe outro tratamento específico eficaz disponível até o momento. Importante ressaltar que há dezenas de estudos clínicos nacionais e internacionais em andamento, avaliando a eficácia e segurança de cloroquina/hidroxicloroquina para infecção por COVID-19, bem como outros medicamentos, e, portanto, essa medida poderá ser modificada a qualquer momento, a depender de novas evidências cientificas.

Entidades como a Associação Brasileira de Saúde Coletiva (Abrasco), em conjunto com diversas instituições cientificas da área de saúde se posicionaram de forma crítica à indicação desses protocolos de tratamento precoce por carecerem de fundamentação cientifica no combate efetivo ao vírus ocasionador da pandemia. Biernath (2021) mostra a complexidade que o tema adquiriu depois que presidentes como Donald Trump e Jair Bolsonaro não só incentivaram o "kit covid" como também realizaram investimentos pesados na fabricação de cloroquina e outros remédios que fariam parte do coquetel da suposta prevenção. Biernath (2021), além de detalhar o processo de elaboração da vacina, usa estudos da Organização Mundial da Saúde (OMS) para afirmar que “[...] as evidências disponíveis sobre benefícios do uso de cloroquina ou hidroxicloroquina são insuficientes, a maioria das pesquisas até agora sugere que não há benefício e já foram emitidos alertas sobre efeitos colaterais do medicamento". No entanto, em diversas manifestações públicas, o Presidente Jair Bolsonaro, além de utilizar os argumentos dos negacionistas, defendeu o uso desses remédios como o melhor tratamento para combater o vírus. O pastor Silas Malafaia faria coro à essas colocações reforçando o negacionismo como forma de combater a pandemia.

\section{Silas Malafaia: fé e pandemia}

Para analisar o vídeo selecionado que contêm a visão do líder religioso, utilizaremos a metodologia da Análise de Conteúdo proposta por Laurence Bardin. Segundo a autora, a Análise de Conteúdo é "Um conjunto de técnicas de análise das comunicações visando obter por procedimentos sistemáticos e objetivos de descrição do conteúdo das mensagens indicadores (quantitativos ou não) que permitam a inferência de conhecimentos relativos às 
condições de produção/recepção (variáveis inferidas) destas mensagens”. (BARDIN, 2006, p. 44).

Neste sentido pode-se inferir que a Análise de Conteúdo é um método eficaz para definir a linha editorial, as concepções práticas e técnicas, o tipo de jornalismo e o conteúdo veiculado nas notícias selecionadas. Os resultados aqui propostos, inspirados na metodologia de Bardin, serão obtidos por meio de três etapas 1) a pré-análise; 2) a exploração do material; 3) tratamento dos resultados, inferência e a interpretação.

A primeira etapa é a fase de organização que, por meio de intuições, o pesquisador tem como objetivo tornar operacionais e sistematizar as ideias iniciais, de maneira a conduzir a um esquema preciso de desenvolvimento das operações sucessivas, num pano de análise. De acordo com Bardin (2006), nesta primeira fase tem-se como meta definir os documentos que serão usados na análise, as hipóteses que nortearam o trabalho, bem como a elaboração de indicadores que fundamentem a interpretação final. Reservou-se essa fase para apresentar o Pastor Silas Malafaia, lembrando que anteriormente explicou-se o vídeo e realizou-se uma revisão bibliográfica de autores selecionados que abordam a midiatização da sociedade e a religião nesse contexto, além de autores que se posicionaram em relação à forma de combate à pandemia.

Após o desenvolvimento da primeira etapa, a segunda é o momento da aplicação da análise, com base na pré-análise. Como argumenta Bardin (2006), "essa fase, longa e fastidiosa, consiste essencialmente em operações de codificação, decomposição ou enumeração, em função de regras previamente formuladas" (BARDIN, 2006, p. 127).

A terceira e última etapa é o momento em que os resultados brutos são tratados de maneira a serem significativos (falantes) e válidos. De acordo com Bardin é nessa etapa que o analista, tendo à sua disposição resultados significativos e fiéis, pode então propor inferências e adiantar interpretações a propósito dos objetos previstos -, ou que digam respeito a outras descobertas inesperadas (BARDIN, 2006, p. 127). Optamos por juntar a segunda e terceira etapa para realizar a análise do material selecionado, no caso, o vídeo em questão.

Silas Lima Malafaia é Pastor neopentecostal formado em psicologia e líder da Igreja Assembleia de Deus Vitória em Cristo. Em seu site oficial ele conta que além de palestrante, conferencista e produzir conteúdo como livros, CDs e DVDs, também possui a segunda maior editora evangélica do país, a Central Gospel. Foi um dos precursores como apresentador de programas evangélicos na televisão brasileira, atualmente chamado de Vitória em Cristo que é veiculado pela AVEC (Associação Vitória em Cristo), uma associação gospel fundada pelo 
líder religioso em 1982 que não só transmite o programa, mas também atende pessoas através de projetos sociais.

Nessa breve apresentação em sua página na internet Silas Malafaia fala sobre os objetivos dentro do programa Vitória em Cristo "[...] sempre anunciei o evangelho, defendo os valores cristãos, a família, a vida e os princípios da palavra de Deus. " (SILAS MALAFAIA, 2020). Além desses meios, o líder neopentecostal possui as redes sociais digitais oficiais na internet, como o Instagram (@silasmalafaia) com 2,9 milhões de seguidores, o Twitter (@PastorMalafaia) com 1,4 milhões de seguidores, o Facebook (Silas Malafaia) com 3 milhões de seguidores e desde 26 de março de 2014, seu canal oficial no Youtube (Silas Malafaia Oficial), com 1,36 milhões de inscritos, onde acumula cerca de 135.998.817 visualizações no total até o momento que escrevemos o texto.

Considerando esse breve levantamento de informações sobre Silas Malafaia na mídia, tem-se um panorama da significativa visibilidade do líder para além do público físico da comunidade de sua Igreja, o que já apresenta a potência da propagação de seu discurso perante seus seguidores. No caso do vídeo "O ódio a Bolsonaro e às religiões em tempo de pandemia" identificamos três categorias centrais: a) crítica às medidas isolacionistas que estariam coibindo o direito de ir e vir garantido pela Constituição; b) campanha manipuladora e falsa contra o presidente Jair Bolsonaro por defender o negacionismo e c) vinculação da política com a religião. A seguir especificaremos mais detalhadamente cada uma delas utilizando as afirmações de Silas Malafaia, as quais geraram cada categoria.

a) críticas contra as medidas isolacionistas

Aqui acontece o questionamento sobre a necessidade de estabelecer um número máximo de pessoas em cultos presenciais, comparando as Igrejas com outros locais (essenciais) que não teriam a mesma exigência, atribuindo essa suposta seletividade à perseguição religiosa e ineficiência da quarentena e da máscara. Pontos identificados aos 00:02:59 - Se dependesse dessas quarentenas aí, sei lá, se dependesse disso aí era para no Brasil "ter" morrido milhares e centenas e centenas de centenas de milhares de pessoas. Tudo de araque, tudo de araque, que até hoje "tá" tudo cheio, tudo lotado, ônibus lotado, tudo aí. Ninguém tem distanciamento, o distanciamento só vale para a igreja, só vale para a religião; e em 00:03:35 - Máscaras só se utilizaram a partir de 15 de maio de 2020 e outra nas comunidades carentes não "teve" comércio fechado, não "teve" distanciamento, não "teve” máscaras, só no Rio de Janeiro tem mais de três milhões de pessoas vivendo em comunidades carentes. 
Outro ponto é o reforço constante da ineficácia do distanciamento social negando a efetividade da quarentena e trazendo à tona novamente que as medidas restritivas seriam seletivas apenas para um determinado grupo social privilegiado e não para as comunidades mais carentes, identificado em 00:01:25 - O que me deixa indignado hoje, é que tem prefeito estabelecendo número de pessoas em cultos de diversas religiões. Só podem 20 ou só podem 30. Aí eu pergunto: tem número limitado dentro de mercado? Só 30 pessoas? Dentro de bancos, só 30 pessoas? Dentro de um ônibus, só 30 pessoas? Não. Puro preconceito e perseguição religiosa.

b) campanha manipuladora e falsa contra o presidente Jair Bolsonaro por defender o negacionismo

Nesse item é feita a apresentação do presidente Jair Bolsonaro como vítima da campanha de descrédito de suas medidas a favor do negacionismo promovida pela imprensa e por partidos de esquerda, questões identificadas em 00:04:20 - Na verdade, Globo, Jornal Nacional, Veja, Folha e Estadão tinham que pedir perdão ao povo brasileiro por "politizarem” a pandemia de maneira vergonhosa, produzindo o pânico do povo que gerou consequências gravíssimas. [...] Terror, Terror. Pânico, morte, só por causa do presidente. O ódio ao presidente porque perderam a mamata de bilhões. Perderam bilhões e querem destruir o cara a qualquer preço a qualquer custo.

Aqui encontra-se o ponto em que se enfatiza a politização do vírus para atacar o presidente 00:03:10 - E Bolsonaro? Aí é que a coisa ficou feia. Politizaram o vírus, a imprensa e os partidos de esquerda, por causa das posições do Bolsonaro. Lembra que Bolsonaro também foi contra isso? Dizendo, olha vai gerar uma catástrofe econômica que vai ser pior do que o coronavírus no Brasil. Além da valorização das medidas presidenciais como o pagamento auxílio emergencial e a aprovação popular do presidente, questões apontadas em 00:07:51 - Bolsonaro na pandemia fez a maior distribuição de renda do mundo em proporção com o PIB. Você viu isso onde? Leu isso onde? Isso é uma vergonha, minha gente. Isso é uma tremenda de uma safadeza da imprensa "graneira" que perdeu dinheiro e quer derrubar o presidente, só que tem uma coisa, o povo está com o presidente.

c) vinculação da política com a religião.

Nesse momento acontece o apelo para que os fiéis não votem em candidatos que estão de acordo com as medidas isolacionistas delimitando número de pessoas para os cultos religiosos 00:01:51 - Quero conclamar evangélicos e católicos que se na sua cidade tem um 
desses prefeitos que adota essas medidas (restritivas) só para as religiões não votem nesses camaradas porque isso não tem nada de ciência. Destacando também a questão da desobediência civil contra as normas de delimitação da circulação de pessoas estabelecidas pelos poderes instituídos no âmbito local e estadual, identificada em 00:00:29 - Eu falei, faz uns tempos atrás que nem presidente nem governador nem prefeito iam fechar a Igreja que eu sou pastor; e 00:08:26 - Eu vou terminar minha fala aqui com o seguinte: não tem nada a ver com pandemia, mas vou deixar esta aqui. Olha, uma conferência que o ministro Barroso participou falando em inglês, que o instituto Fernando Henrique promoveu. Olha o que esse cara fala de Bolsonaro (Imagem com teto onde se le "Temos um presidente defende a tortura e a ditadura") isso é uma vergonha, se um cada desses aqui tivesse leis seria esse cara seria impedido de ser ministro. Que moral tem um cara desses para julgar a chapa de Bolsonaro no STE? Nenhuma!

\section{Inferências}

Retomando o conteúdo do vídeo do Pastor Silas Malafaia fica evidente a supervalorização da religião como elemento ativo com capacidade de determinar ações dos fiéis, inclusive acima das normas emanadas dos poderes instituídos. Percebe-se uma distorção e parcialidade em seu pronunciamento ao apresentar dados e realizar afirmações genéricas, como usar informações para dizer que morrem no mundo um determinado número de pessoas, ou mais, do que no Brasil por conta da pandemia. A questão envolvida nesse tipo de afirmação é que, além de defender o negacionismo aplicado pelo Governo Federal no combate a pandemia, isenta o Presidente de qualquer responsabilidade, inclusive este é elogiado pelas medidas adotadas para minimizar os problemas sociais fruto da retração econômica, enquanto condena prefeitos e governadores por adotarem posicionamento contrário.

Como é sabido, existiam divergências entre as falas e opiniões do Presidente e as medidas tomadas por alguns governadores. A polêmica chegou ao Supremo Tribunal Federal (STF) que decidiu pela atuação em conjunto da União, estados e prefeituras na adoção de medidas para proteger a população. O que se observa no pronunciamento do pastor é a desqualificação das medidas consideradas corretas pelas autoridades sanitárias para combater a pandemia, sempre poupando o Presidente Jair Bolsonaro.

Nesse sentido a maneira de inserir a religião dialogando com as medidas governamentais se coloca como pertinente no caso estudado. Essa prática já fora anunciada por Bratosin (2017) para quem a midiatização do fenômeno religioso acompanha a transformação experimentada pela mídia tornando-se presente e ativa na sociedade. Martino (2012) avança nas colocações ao afirmar que essa ampliação da presença da religião nas mídias se traduz em REVISTA RELEGENS THRÉSKEIA - 2021 - UFPR 
alinhamentos políticos fortalecendo a denominada bancada evangélica. Por sua vez, Gouvêa Neto (2017) enxerga nesse tipo de manifestação, como a promovida por Silas Malafaia, um instrumento a mais para reforçar e criar a identidade evangélica. No caso a identidade reforçaria ideias claramente negacionistas como podemos observar no pronunciamento do pastor que ao mesmo tempo identifica seus potenciais inimigos: notadamente a imprensa, os grupos excluídos socialmente e os partidos de esquerda.

Como pôde ser verificado o pastor mente para sustentar que a mídia tem uma visão distorcida. No vídeo ele afirma que os meios de comunicação apresentam a pandemia como sendo um problema exclusivamente do Brasil. O que constatamos é que em momento algum, no contato que tivemos com os meios de comunicação consultados em nossa pesquisa, encontramos alguma afirmação que colocasse a pandemia como uma questão apenas brasileira. Ao contrário, se fez referência constante a esses modelos de combate pensando qual seria mais útil para o Brasil.

Ele segue seu pronunciamento retomando a negação a respeito das medidas de distanciamento social, uso de máscara e fechamento temporário do comércio, justificando que essas determinações seriam para benefício de prefeitos e governadores. Como visto, autores como Gottschall (2020) e Andreen (2020), ambos membros do Instituto Mises, já tinham defendido essas ideias negacionistas se alinhando claramente contra os isolacionistas. A questão central e relevante, desde nosso ponto de vista, é que constatamos a existência de pensadores e de ideias que circulam no âmbito religioso, mas que se fazem presentes em institutos e organizações que disseminam esses princípios criando as condições para formar um grupo e um pensamento conservador na sociedade, não apenas no âmbito religioso. Embora Silas Malafaia não especifique suas fontes, a leitura desses escritores negacionistas revela claramente como se elaboram ideias e pontos de vista que se naturalizam usando a midiatização como instrumento de divulgação, tanto para a sociedade como para os fiéis evangélicos consumidores dessas mídias. Silas Malafaia também chega a defender tratamentos com a cloroquina.

Como já visto ao decorrer do referencial teórico e de acordo com Botelho (2018, p. 120) “[...] as escolhas religiosas certamente fundamentam as decisões morais do indivíduo, figurando como razões morais determinantes para a sua conduta". Tendo em vista esses aspectos e analisando as falas do pastor Silas Malafaia do material objeto de análise, entende-se que apesar de não se tratar de um pronunciamento religiosamente formal, este apresenta-se através de uma figura tida como representante da palavra de Deus e que é detentora de visibilidade e 
credibilidade entre os fiéis, logo, a banalização de um tema grave de saúde pública pode refletir em consequências negativas expressivas para a população.

De acordo com uma matéria publicada pelo G1 em 3 de setembro de 2020, "Brasil terminou agosto com 28.947 mortes pela Covid-19, apontam secretarias e Saúde”. Exatamente no mês em que o vídeo de Silas Malafaia é postado. Atualmente, em meados de 2021, segundo o consórcio de veículos de imprensa, o Brasil registra aproximadamente 563 mil mortes pela doença (UOL, 2021) e a cifra não para de subir. Ou seja, os números se tornam cada vez mais agravantes e apesar das vacinas estarem sendo aplicadas na população o ritmo é lento, até agora o equivalente a $63,77 \%$ de brasileiros receberam a primeira dose e apenas $32,32 \%$ da população receberam a segunda dose $(\mathrm{G} 1,2021)$.

Nesse sentido as melhores medidas de contenção do vírus são, de acordo com estudos científicos: distanciamento social, uso de máscaras e higiene reforçada, toda elas negligenciadas pelos negacionistas, como visto no item 3 do texto e com as quais concordamos plenamente. Nas palavras de Silas Malafaia, o distanciamento e a quarentena recomendados seriam de "araque". A imprensa estaria fazendo alarde quanto a gravidade do assunto apenas para prejudicar o Presidente da República, o qual tem feito, desde o início da pandemia, declarações polêmicas e contraditórias sobre a emergência do cenário, negando propostas de compra de vacinas de países do exterior, negando a eficácia do uso de máscaras e da necessidade do distanciamento, além de relativizar os números de mortes registradas.

\section{Considerações finais}

Não há de se retirar a importância das religiões dentro das estruturas sociais, visto que se trata de um fenômeno presente nas mais diversas culturas há milênios. A discussão abordada não tem como finalidade questionar esses valores, mas sim contextualizar sua relevância em um cenário atual em que as vozes dos sujeitos são ampliadas por recursos midiáticos e assim fazem parte de uma nova forma de estabelecer significados sobre temas que são externos a práticas de crença e fé e abrangem a sociedade em um sentido mais amplo.

A visibilidade, bem como a credibilidade atribuídas a alguém, nesse caso, um líder religioso ligado ativamente a causas políticas e sociais, podem de fato interferir não só em opiniões como também em comportamentos de indivíduos na sociedade, sem dizer que estes, ao reforçarem apoio a candidatos que compactuam com suas ideias acabam pregando também influências sobre os votos de seus fiéis ou seguidores e adicionam a essa relação um viés político mais direto ainda. Ficou bem evidente o uso de falas direcionadas para votos em candidatos identificados com os valores da igreja, inclusive a utilização da perseguição como 
forma de sensibilizar ainda mais os fiéis na hora de decidir sua escolha política. Genericamente se coloca à esquerda todos os contrários ao pensamento do pastor.

Claro que não se pode reduzir a mudança de opinião imediata do receptor ao ter contato com uma figura com potencial influenciador, pois dessa forma se faria uma generalização do indivíduo como mero receptor, isento de senso crítico, sem capacidade de questionar e ignorando a influência de outros meios na formação de opinião e pensamento, mas igualmente, há de se considerar o potencial dessas vozes, pois essas também se tornam agentes influenciadores capazes de exercerem papéis significativos como modelos de ação.

A partir do momento em que o fiel visualiza uma figura referencial relativizando questões de saúde pública e reduzindo a dimensão de uma pandemia apenas a interesses políticos e midiáticos as consequências não se resumem somente a diferenças ideológicas ou de concepções, mas, neste caso, diz respeito a manutenção da vida e inerentemente ao benefício coletivo. Aqui cabe a possibilidade de continuar as discussões aprofundando a investigação sobre as raízes do negacionismo científico e sua relação tênue com as concepções religiosas seculares.

Finalmente destacamos que além da fala de Silas Malafaia existem organizações que elaboram teorias que posteriormente são apropriadas e disseminadas formando o que denominamos de pensamento conservador. No caso estudado, o negacionismo casa em termos de concepções com a visão política e religiosa, tanto do pastor Silas Malafaia como com a do Presidente citado e identificado com esse tipo de pensamento. Religião, mídia, política e o Instituto Mises no caso estudado, convergem em ideias e entendimentos em relação a pandemia. Isso nos faz pensar na relevância dessa constatação que mereceria estudos mais detalhados, mas que já apontam para a importância e dimensão ampla do tema tratado.

\section{Referências}

ANDREEN, F. Políticos destruíram o mercado e ignoraram direitos humanos com um alarmante entusiasmo. Mises Brasil, 2020. Disponível em:<https://www.mises.org.br/article/3247/politicos-destruiram-o-mercado-e-ignoraramdireitos-humanos-com-um-alarmante-entusiasmo>. Acesso em: 28 ago. 2021.

BARBERO, J. Tecnicidades, identidades, alteridades: mudanças e opacidades da comunicação no novo século. In: MORAES, D. Sociedade Midiatizada. Rio de Janeiro: Mauad, 2006. Parte I, p.51-79.

BARDIN, L. Análise de Conteúdo. São Paulo: Edições 70, 2006. 
BERARDI, F. “A pandemia reativou o futuro. Há condições para reformatar a mente social”. El País, 2020. Disponível em: <https://brasil.elpais.com/cultura/2020-06-02/franco-berardi-apandemia-reativou-o-futuro-vejo-condicoes-para-a-reformatacao-igualitaria-da-mentesocial.html>. Acesso em: 28 ago. 2021.

BIERNAT, A. Tratamento precoce 'Kit covid é kit ilusão': os dados que apontam riscos e falta de eficácia do suposto tratamento. BBC Brasil, 2020. Disponível em: <https://www.bbc.com/portuguese/brasil-55775106>. Acesso em: 28 ago. 2021.

BOTELHO, M. O problema do discurso religioso nas sociedades líquidas e a efetivação do direito fundamental à liberdade de crença. Revista Direito e Liberdade, Natal, v. 20, n.1, p. 113 - 140, 2018. Disponível em: <https://redib.org/Record/oai_articulo1505890-o-problemado-discurso-religioso-nas-sociedades-1\%C3\%ADquidas-e-a-efetiva\%C3\%A7\%C3\% A3o-dodireito-fundamental-\%C3\% A0-liberdade-de-cren $\% \mathrm{C} 3 \% \mathrm{~A} 7 \mathrm{a}-$-problem-religious-discourseliquid-societies-enforcement-fundamental-right-freedom-belief >. Acesso em: 4 jun. 2021.

BRATOSIN, S; PAES, P. Midiatização da Religião. Revista Pauta Geral - Estudos em Jornalismo, Ponta Grossa, v. 4, n.1, p.144- 51, 2017. Disponível em: <https://revistas2.uepg.br/index.php/pauta/article/view/9830>. Acesso em: 3 jun. 2021.

CAPONI, S. Covid-19 no Brasil: entre o negacionismo e a razão neoliberal. Estudos Avançados, 2020.2 Disponível em: <https://www.scielo.br/j/ea/a/tz4b6kWP4sHZD7ynw9LdYYJ/?format=pdf>. Acesso em: 24 ago. 2020.

CARRANÇA, T. PIB: Pandemia agrava o que já seria pior década de crescimento no Brasil em mais de um século. BBC Brasil, 2021. Disponível em: <https://www.bbc.com/portuguese/brasil-56257245>. Acesso em: 8 ago. 2021.

CASTELLS, M. O poder da comunicação. Lisboa: Fundação Calouste Gulbenkian, 2013.

CUNHA, M. Elucidações contemporâneas nos estudos brasileiros em mídia e religião: a perspectiva das mediações culturais e comunicacionais. Revista FAMECOS, Porto Alegre, v.23, n.2, 2016. Disponível em: <https://revistaseletronicas.pucrs.br/ojs/index.php/revistafamecos/article/view/22280>. Acesso em: 9 jun. 2021.

CUNHA, M. Interseções e interações entre mídia, religião e mercado: um objeto dinâmico e instigante. HORIZONTE - Revista de Estudos de Teologia e Ciências da Religião, Belo Horizonte, v. 12, n. 34, p. 284-289, 2014. Disponível em: <http://periodicos.pucminas.br/index.php/horizonte/article/view/P.2175-

5841.2014v12n34p284>. Acesso em: 5 jun. 2021.

GOTTSCHALL, C. Coronavírus: muitos erros, nenhum acerto, e o paroxismo da estupidez. Mises Brasil, 2021. Disponível em: <https://www.mises.org.br/article/3264/coronavirusmuitos-erros-nenhum-acerto-e-o-paroxismo-da-estupidez>. Acesso em: 08 ago. 2021.

MALAFAIA, Silas. O ódio a Bolsonaro e às religiões em tempo de pandemia. Youtube, 27 ago. 2020. Disponível em: <https://www.youtube.com/watch?v=u4xTMUB_als>. Acesso em: 5 jun. 2021. 
MAPA da vacinação contra Covid-19 no Brasil. G1, 2021. Disponível em: <https://especiais.g1.globo.com/bemestar/vacina/2021/mapa-brasil-vacina-covid/>. Acesso em: 9 set. 2021.

MARTINO, L. A religião midiatizada nas fronteiras entre público e privado: uma abordagem teórico-crítica. Revista C-Legenda, Niterói, n.26, 2012. Disponível em: <https://periodicos.uff.br/ciberlegenda/article/view/36904>. Acesso em: 9 jun. 2021.

MARTINO, L. Mediação e midiatização da religião em suas articulações teóricas e práticas: um levantamento de hipóteses e problemáticas. In: MATTOS, M; JANOTTI, J; JACKS, N. (Orgs.). Mediação e Midiatização. Salvador: EDUFBA; Brasília: Compós, 2012, Parte I, p. 219-244.

MARTINS, P. Entidades científicas fazem carta crítica a protocolo de tratamento precoce da Covid-19 em SC. Abrasco, 2020. Disponível em: $<$ https://www.abrasco.org.br/site/noticias/entidades-cientificas-e-da-area-da-saude-fazemcarta-critica-a-protocolo-de-tratamento-precoce-de-covid19-em-santa-catarina/50228/> . Acesso em: 28 ago. 2021.

MINHA História. Silas Malafaia, 2020. Disponível em: <https://www.silasmalafaia.com/minha-historia/>. Acesso em 11 jun. 2021.

MOREL, A. Negacionismo da Covid-19 e educação popular em saúde: para

além da necropolítica. Trabalho, Educação e Saúde, Rio de Janeiro, v. 19, 2021. Disponível em: < https://www.scielo.br/j/tes/a/pnVbDRJBcdHy5K6NSc4X65f/ >. Acesso em: 10 jun. 2021.

NETO, A. O uso político da religião e o uso religioso da política: como a defesa de pautas morais indica uma compressão de gênero. Revista INTERAÇÕEES, Belo Horizonte, v. 12, n. 22, p. 323-342, 2017. $<$ http://periodicos.pucminas.br/index.php/interacoes/article/view/P.1983-

2478.2017v12n22p323>. Acesso em: 10 jun. 2021.

NODARI, P. C.; KRINDGES, S. M. Notas sobre ética, religião e mídia. Revista INTERAÇÕES, Belo Horizonte, v. 9, n. 15, p. 144-167, 2014. Disponível em: <http://periodicos.pucminas.br/index.php/interacoes/article/view/P.1983-

2478.2014v9n15p144>. Acesso em: 8 jul. 2021.

NOTA INFORMATIVA N ${ }^{o}$ 6/2020-DAF/SCTIE/MS. Ministério público do Estado do Maranhão, 2020. Disponível em: <https://www.mpma.mp.br/arquivos/CAOPSAUDE/MS--0014223901---Nota-Informativa-n---6-2020-DAF-SCTIE-MS.pdf〉. Acesso em: 13 ago. 2021.

OLIVEIRA, T. Droga queridinha de Bolsonaro, cloroquina está no centro de uma disputa política. Carta Capital, 2020. Disponível: <https://www.cartacapital.com.br/politica/drogaqueridinha-de-bolsonaro-cloroquina-esta-no-centro-de-uma-disputa-politica/>. Acesso em: 15 ago. 2021. 
OMS, Europa e Anvisa não recomendam cloroquina para tratar a Covid-19. CNN, 2021. Disponível em: <https://www.cnnbrasil.com.br/saude/2021/05/25/entenda-as-recomendacoesdas-instituicoes-de-saude-contra-o-uso-de-cloroquina>. Acesso em: 4 jun. 2021.

PENÃ-ALFARO, A. Estratégias discursivas de persuasão em um discurso religioso neopentecostal, 2005. 246 f. Tese (Doutorado em Linguística) apresentada ao Programa de Pós-Graduação em Letras da Universidade Federal de Pernambuco, Recife. Disponível em: <https://repositorio.ufpe.br/handle/123456789/7707>. Acesso em: 8 jun. 2021.

PENAFORTE, T. O negacionismo enquanto política: o debate da cloroquina em uma comissão parlamentar. Cadernos de Saúde Pública, 2021. Disponível em: <https://www.scielo.br/j/csp/a/9BjJnwy7vBNnkVWn4w94kyx/?lang=pt\&format=pdf >. Acesso em: 24 ago. 2021.

PINHEIRO, L. Brasil termina agosto com 28.947 mortes pela Covid-19, apontam secretarias de Saúde; especialistas alertam que a pandemia não acabou. G1, 2020. Disponível em: <https://g1.globo.com/bemestar/coronavirus/noticia/2020/09/03/brasil-termina-agosto-com28947-mortes-pela-covid-19-apontam-secretarias-de-saude-especialistas-alertam-quepandemia-nao-acabou.ghtml>. Acesso em: 5 jun. 2021.

PERINI, E. O que move as fake news e o negacionismo científico? [Entrevista concedida a] Marco Weissheimer. Sul 21, 27 nov. 2019. Disponível em: $<$ https://outraspalavras.net/outrasmidias/o-que-move-as-fake-news-e-negacionismocientifico/>. Acesso em: 2 set. 2021.

QUEM somos. Mises Brasil, 2021. Disponível em: 〈https://www.mises.org.br/About.aspx>. Acesso em 06 out. 2021.

SANTOS, B. A cruel pedagogia do vírus. ABEn Nacional, 2021. Disponível em: <https://www.abennacional.org.br/site/wpcontent/uploads/2020/04/Livro_Boaventura.pdf>. Acesso em: 1 ago. 2021

SILVA, L. Religião e Política no Brasil. Revista Latinoamérica, Cidade Do México, n.64, p.223-256, 2017.2 Disponível em: <http://www.scielo.org.mx/scielo.php?script=sci_arttext\&pid=S1665-85742017000100223 >. Acesso em: 11 jun. 2021.

TOTAL de mortos pela Covid-19 no Brasil chega a 563.151. Uol Economia, 2021. Disponível em: <https://economia.uol.com.br/noticias/reuters/2021/08/08/total-de-mortos-pela-covid-19no-brasil-chega-a-563151.htm>. Acesso em: 3 jun. 2021.

VALLA, V. Mediadores, saúde e religião em Educação popular. Revista Cultura Vozes, Rio de Janeiro, v.96, n.5, 2002. Disponível em: <https://www.victorvincentvalla.com.br/wpcontent/uploads/Mediadores-sa\%C3\%BAde-e-religi\%C3\%A3o-emeduca\%C3\%A7\%C3\%A3o-Popular.pdf>. Acesso em: 9 jun. 2021.

VEJA quais deputados e senadores fazem parte da bancada evangélica. Congresso em foco, 2020. Disponível em: <https://congressoemfoco.uol.com.br/legislativo/veja-quais-deputadose-senadores-fazem-parte-da-bancada-evangelica/>. Acesso em: 10 jun. 2021. 